\title{
Rafael Altamira e Fidelino de Figueiredo: Intelectuais, exílio e reconhecimento no início do século $\mathrm{XX}^{*}$
}

\author{
Rafael Altamira and Fidelino de Figueiredo: Intellectuals, exile and recognition in the \\ early twentieth century
}

Ana Paula Barcelos Ribeiro da Silva

Universidade do Estado do Rio de Janeiro Faculdade de Formação de Professores anapaulabarcelos@gmail.com

\begin{abstract}
Resumo: Neste artigo analisamos, a partir dos casos de Fidelino de Figueiredo e Rafael Altamira, a experiência de exílio de intelectuais ibéricos nas Américas no início do século XX. No contexto de guerras e ascensão dos fascismos, estes intelectuais, um português e o outro espanhol, buscaram refúgio no Brasil e no México, construindo redes de sociabilidade, reconhecimento e inserção institucional. Assim, vivenciaram o afastamento e as angústias do exílio, mas, ao mesmo tempo, produziram conhecimento e refletiram sobre suas próprias experiências. Utilizamos como fontes algumas de suas obras ligadas à história e à literatura e correspondências trocadas entre eles e com outros pares intelectuais de sua época.
\end{abstract}

Palavras-chave: Intelectuais, exílio, reconhecimento.

\begin{abstract}
In this article we analyse, from the cases of Fidelino de Figueiredo and Rafael Altamira, the experience of exile of Iberian intellectuals in America in the beginning of the $\mathrm{XX}^{\text {th }}$ century. In the context of wars and ascension of fascisms, these intellectuals, one Portuguese and the other Spanish, sought refuge in Brazil and Mexico, building sociability networks, recognition and institutional insertion. Like this, they experienced the remoteness and the anguishes of exile, but, at the same time, produced knowledge and reflected about their own experiences. As sources, we use some of their works related to History and Literature and correspondences changed between them and with other intellectual partners of their time.
\end{abstract}

\footnotetext{
* Este artigo é fruto das discussões desenvolvidas no capítulo IV da tese de doutorado defendida no Programa de Pós-graduação em História da UFF em 2011 e que deu origem ao livro Diálogos sobre a Escrita da História: Brasil e Argentina (1910-1940), publicado no mesmo ano pela FUNAG. Aqui destacamos especificamente a questão do exílio intelectual, com ênfase em suas características e ambiguidades diante da ascensão dos fascismos europeus na primeira metade do século XX. A pesquisa de doutorado foi realizada com bolsa CAPES.
} 


\section{Introdução}

Neste artigo desenvolvemos uma reflexão acerca das experiências de exílio de dois intelectuais ibéricos na primeira metade do século $\mathrm{XX}$ diante das guerras e da ascensão dos fascismos europeus. Neste período, o espanhol Rafael Altamira e o português Fidelino de Figueiredo buscaram refúgio no México e no Brasil, respectivamente, em razão da perseguição política sofrida em seus países de origem. Destacamos, a partir de suas obras e de algumas correspondências, o caráter de afastamento e sofrimento do exílio e, ao mesmo tempo, o potencial de produtividade que ele traz ao desafiar estes sujeitos históricos na compreensão da realidade vivida, o que gera, por vezes, elaboração ou reformulação de ideias. Pensamos ainda suas próprias leituras sobre o exílio e seu impacto subjetivo em suas trajetórias, sobretudo no que se refere à busca por reconhecimento. Ao mesmo tempo, analisamos, embora tangencialmente, as redes de sociabilidade construídas no exílio, sobretudo a partir da inserção institucional nos países que os receberam. Lembramos que, como historiadores (entre outros papeis de intelectuais multifacetários), Altamira e Figueiredo também olharam para o passado e construíram uma leitura de defesa da aproximação entre antigas metrópoles e colônias no início do século XX. Assim, pensamento histórico, experiências políticas e exílio se encontram na análise das trajetórias destes intelectuais ibéricos. Com estes objetivos, apresentamos, em primeiro lugar, um panorama de suas trajetórias e dos aspectos nos quais elas se encontram. Em seguida, pensamos as ambiguidades da experiência do exílio, a sensação de não ser e não pertencer e, concomitantemente, o quanto produziram e construíram a partir da atuação na IberoAmérica. Por fim, apontamos as relações entre exílio, reconhecimento e ressentimento diante da perseguição, da inadaptação e do afastamento do país de origem. 


\section{Altamira e Figueiredo: Trajetórias e Ideias}

Distintos ideologicamente, Altamira e Figueiredo se aproximaram em termos de perfil intelectual. Altamira nasceu em 1866 e morreu em 1951 no México, exilado da ditadura franquista. Foi jurista, historiador do direito, professor e crítico literário. Logo nos primeiros anos do século XX intensificou o contato com intelectuais estrangeiros e começou a investir no intercâmbio com a Hispano-América baseado na defesa de uma história e uma língua comuns. Entre 1909 e 1910, viajou pelo continente americano, representando a Universidade de Oviedo, "com o objetivo de renovar os quase inexistentes laços da Espanha com suas antigas colônias e ampliar o intercâmbio docente entre sua própria universidade e as hispano-amaericanas" (AYALA, 2006: 25). Para isto, esteve na Argentina, no Uruguai, no Chile, no Peru, no México, em Cuba e nos Estados Unidos ditando cursos e realizando projetos e convênios. Muito envolvido em ações pedagógicas, principalmente no que tange ao ensino da história, entre 1911 e 1913 assumiu a Dirección General de Primera Enseñanza criada pelo Ministério da Instrução Pública na Espanha. Nele tomou medidas relacionadas à melhoria dos salários, da formação dos professores e das condições materiais das escolas. Renunciou ao cargo em 1913 devido à hostilidade dos setores conservadores católicos, insatisfeitos com suas medidas liberais e ideias positivistas. Durante a Primeira Guerra, apoiou os Aliados, seguindo a tendência de muitos intelectuais espanhóis considerados progressistas, mesmo diante da neutralidade da Espanha no conflito. Para ele, os Aliados seriam "representantes do espírito democrático liberal” (AYALA, 2006: 28). No mesmo período, tornou-se senador vinculado ao partido liberal de Romanones, atuando no assessoramento de questões educativas.

Em 1931, com o advento da Segunda República, de acordo com María de los Ángeles Ayala (2006), ao mesmo tempo em que Altamira acreditou na possibilidade de desenvolvimento de um regime democrático na Espanha, se manteve preocupado com o fortalecimento do fascismo na Europa. Por isto, se empenhou em difundir ideais pacifistas como meio de evitar os conflitos bélicos. Assim, foi indicado pela primeira vez ao Prêmio Nobel da Paz em 1933. Com a Guerra Civil Espanhola (1936-1939) saiu da Espanha e instalou-se em Haia, em cuja corte atuava como juiz internacional. Lá permaneceu até 1940 quando a Holanda foi ocupada já durante a Segunda Guerra. A partir de então se estabeleceu na França. Neste contexto, preocupou-se em não expressar 
posições extremadas, mas demonstrou-se aflito com os rumos da República e o enfraquecimento da democracia no caso de uma vitória do General Francisco Franco. Ainda segundo Ayala, Altamira criticou "a violência de um lado e do outro, os procedimentos ditatoriais dos mandos franquistas e a desorganização reinante na esfera republicana" (AYALA, 2006: 32). Simultaneamente, repreendeu os países democráticos que não teriam apoiado a República espanhola, permitindo a ascensão fascista. O início da Segunda Guerra gerou ainda maior preocupação, já que seus ideais de justiça, liberdade e pacifismo se diluíam naquele contexto. Após a vitória de Franco e a implantação do regime ditatorial na Espanha, decidiu que não regressaria ao país enquanto este vigorasse. Com dificuldades financeiras, saiu da França e com o auxílio de colegas mexicanos e a proteção diplomática da Argentina, partiu para Lisboa e depois para Nova York até que, em novembro de 1944, transladou-se para o México onde permaneceu até a morte sem ver o fim do regime franquista, o que ocorreria apenas na década de 1970. Em homenagem a sua atuação pacifista foi ainda mais uma vez indicado ao Prêmio Nobel da Paz neste mesmo ano. Sua candidatura contou com cerca de 400 adesões, dentre instituições e intelectuais bastante reconhecidos internacionalmente.

Figueiredo, que viveu entre 1889 e 1967, foi professor, historiador e crítico literário, como Altamira. Foi também Ministro da Instrução Pública em Portugal, cargo que exerceu entre 1914 e 1915, anos iniciais da República portuguesa, e diretor da Biblioteca Nacional de Lisboa por duas vezes, entre 1918 e 1919 e em 1927. Após a instauração do Estado Novo em Portugal em 1926, exilou-se na Espanha, entre 1927 e 1929, por ter participado ativamente de um movimento de oposição ao regime. Lá foi influenciado por forte hispanismo, sendo este período considerado de grande importância em seu desenvolvimento intelectual. Esta tendência já era marcante em seu pensamento desde 1913 quando foi estudar em Madrid e tomou contato com as renovações iniciadas por Marcelino Menéndez y Pelayo. Por ocasião desta viagem, manteve contato ainda com outras importantes figuras das inovações intelectuais e historiográficas espanholas, dentre eles Rafael Altamira. Sua aproximação com a Espanha de Altamira foi intensa ao longo de toda sua trajetória intelectual. Fidelino de Figueiredo foi considerado, inclusive, o mais importante representante português da geração de 1898 em Portugal, influenciado principalmente por Miguel de Unamuno, cuja obra conheceu mais a fundo através do exílio em Madrid e da correspondência com 
o escritor espanhol. Sobre a Espanha chegou a escrever duas obras: As duas Espanhas (1932) e Pyrenne (1935).

No Brasil esteve duas vezes: a primeira em uma curta viagem de trabalho em 1920, a segunda por um período bem mais prolongado de 13 anos durante seu segundo exílio já no governo de Salazar, entre 1938 e 1951. Aqui dirigiu a cadeira de Literatura Portuguesa da Faculdade de Filosofia, Ciências e Letras da Universidade de São Paulo e deixou discípulos e influências intelectuais. Seus vínculos com o Brasil, contudo, remontam a 1913 quando ingressou no IHGB sob a indicação de Viveiros de Castro. Ingressou também na Academia Brasileira de Letras em 1942 com candidatura proposta por Alceu Amoroso Lima. Além destes, dentre os intelectuais brasileiros com os quais Figueiredo se correspondeu entre as décadas de 1910 e 1960, estiveram Manuel Bandeira, Luís da Câmara Cascudo, Jackson de Figueiredo, o Padre Leonel Franca, Gilberto Freyre, Oliveira Lima, Afrânio Peixoto e Jonathas Serrano. A maioria marcada por vínculos diretos ou indiretos com o pensamento católico. Possuía orientação monarquista, antipositivista, liberal conservadora e católica. Foi crítico direto de Teófilo Braga, positivista e presidente do governo provisório português entre 1910 e 1911.

Vemos, portanto, haver alguns pontos de afinidade entre ambos. Afinidades que os aproximam principalmente quanto à defesa da reaproximação de seus países com suas antigas colônias em busca de raízes e tradições comuns e da retomada de um contato interrompido com os processos de independência no início do século XIX. Manifestam-se ainda na oposição de ambos aos regimes fascistas nos anos 1930 e 1940. A defesa da paz também deve ser destacada. A atuação pacifista de Altamira encontra paralelo nas ideias de Figueiredo. Segundo Maria José Wehling (1983), ele repelia o engajamento intelectual, mas também o seu isolamento. Seria preciso entender para servir a humanidade. Assim, em uma fase universalista na década de 1930, influenciado pelas guerras, preocupou-se com a construção da paz e com o cosmopolitismo. Michael Löwy (1989) propõe a aplicação do conceito de afinidades eletivas para se pensar a relação entre messianismo judaico e utopia social na passagem do século XIX para o XX. Tratando-se de uma relação dialética particular entre duas esferas distintas, não redutível a explicações causais, as afinidades eletivas seriam favorecidas por condições históricas e sociais que envolvem as diferentes esferas em questão. Assim, um católico de orientação monarquista e um republicano encontraram na primeira metade do século $\mathrm{XX}$ interesses temáticos e condições históricas e sociais que fortaleceram sua 
aproximação, sobretudo no contexto de recrudescimento da perseguição fascista aos intelectuais na Europa.

Altamira se empenhou em colocar em prática a retomada das relações entre antigas colônias e metrópoles bem mais que Figueiredo, de modo a criar todo um programa de desenvolvimento das relações entre a Espanha e os países hispanoamericanos. Altamira foi também liberal e positivista - com fortes influências do positivismo francês. Buscava através do método, a objetividade na história e queria romper com o pessimismo espanhol característico da geração de 1898. Regeneracionista, acreditava na possibilidade do renascimento espanhol por meio do americanismo (JUAN, 2002). As antigas colônias americanas seriam, em sua opinião, o maior exemplo do poder civilizador e a maior contribuição da Espanha para a história. Estes ideais direcionaram seu pensamento e sua ação política, o que envolvia uma série de projetos educacionais para as massas (JUAN, 2003). Fidelino de Figueiredo, com uma visão muito próxima sobre o Brasil, era, no entanto, um ácido combatente do positivismo personificado, no Portugal da sua geração, por Teófilo Braga. No lugar da objetividade e da cientificidade defendidas por Altamira, buscava a construção da identidade portuguesa por meio de aspectos mais emocionais e espirituais e menos racionalistas. Opostos, porém semelhantes, o fato é que Altamira e Figueiredo viveram as mesmas questões conjunturais numa Península Ibérica em constante conflito durante a primeira metade do século XX, se opuseram aos rumos autoritários da República e aos governos ditatoriais em seus países e acabaram percebendo nas antigas colônias uma possibilidade pacífica, um refúgio diante da rejeição que sofreram. Não por acaso Figueiredo viveu 13 anos no Brasil e Altamira 7 anos no México. Coincidentemente, em 1951, enquanto Altamira morria exilado, Figueiredo retornava a Portugal. Assim, por meio do diálogo com pares intelectuais ibero-americanos contribuíram ainda para a aproximação entre as duas margens do Atlântico historicamente interligadas.

O paralelo que aqui construímos entre Altamira e Figueiredo não se dá apenas pela proximidade contextual, pelas afinidades e pelos interesses em comum. Eles se conheceram e trocaram correspondências. Não tivemos acesso à correspondência de Altamira que nos permitiria aprofundar este diálogo, mas encontramos algumas cartas suas a Figueiredo na correspondência passiva deste último. No acervo, com cerca de 11.000 cartas, constam poucas enviadas pelo espanhol, apenas 5 no total, datadas das décadas de 1930 e 1940, algumas enviadas da Espanha, outras do México já durante o exílio. Contudo, apesar de poucas, estas cartas comprovam nossa interpretação acerca 
das afinidades intelectuais entre eles, mesmo diante de suas diferenças teóricas e ideológicas. Afinidades que, conforme dissemos, entendemos também como eletivas na medida em que aproximam sujeitos distintos em um contexto histórico que as favorece. As cartas foram escritas e enviadas entre os anos de 1934 e 1944, ou seja, em um contexto histórico, político e pessoal bastante relevante para a compreensão dos dilemas por eles experimentados. São cartas ainda em tom bastante pessoal e amigável e marcadas por alguns projetos intelectuais conjuntos.

Neste período, ocorreram a Guerra Civil Espanhola, o avanço nazifascista e a Segunda Guerra na Europa. Em Portugal e na Espanha, a partir respectivamente de 1932 e 1939, Salazar e Franco ascenderam ao poder, dando início a políticas autoritárias que incluem censura e perseguição a intelectuais e políticos de oposição. Tanto Figueiredo quanto Altamira haviam assumido cargos públicos importantes nos governos anteriores - Figueiredo já durante a República, nos anos 1920, e Altamira ainda durante a monarquia espanhola. Ambos se tornaram vulneráveis às mudanças políticas da década de 1930 e buscaram, então, o exílio. Figueiredo chegou ao Brasil em 1938, aos 49 anos, e Altamira se encontrou com suas filhas já exiladas no México em 1944, aos 78 anos. Embora estes acontecimentos não apareçam nas cartas, é preciso ver que serviram como pano de fundo para as escolhas pessoais e os projetos profissionais destes indivíduos de gerações diferentes, mas com diálogos, afinidades e experiências de exílio.

\section{As Ambiguidades da Condição de Exilado}

Na década de 1950, período em que voltava a Portugal, após 13 anos vivendo no Brasil, Fidelino de Figueiredo publicava Um coleccionador de angústias. Retratando a trajetória de um homem e suas angústias desde o nascimento e a formação escolar até a doença e consequente morte, o autor tece, em terceira pessoa, as experiências deste homem que, na verdade, é um retrato de si mesmo. Assim, apresentava suas angústias e a crise contemporânea que atingia a intelectualidade após as transformações e conflitos políticos da primeira metade do século XX. Dentre estas angústias estaria o exílio:

— Nada há mais envenenado que a mentalidade desse exilado. Nada esquece e nada aprende, como os velhos Bourbons, só espera a hora de saldar as suas contas com juros acumulados. Eu não tenho contas a cobrar, tenho deveres a cumprir para com a minha terra e para com a vida. 
E a angústia política passou-lhe, graças à boa companhia dos seus amigos espanhóis [...] (FIGUEIREDO, 1953: 178).

Exílio (o primeiro deles, entre 1927 e 1929) em Madrid, com os "amigos espanhóis", não em Paris como o de muitos intelectuais na época, pois não pretendia ser "um exilado político profissional ou clássico" (FIGUEIREDO, 1953: 178). Exilado que deveria aprender, sem se engessar, e manter os compromissos com a terra que o rejeitou. Aprendizado que ele teria recebido, por exemplo, do escritor espanhol Miguel de Unamuno, quem muito o influenciou na temática da angústia focalizada no livro. Aproximando-se do fim de sua trajetória acadêmica e no momento de retorno ao país de origem, algo que ele sempre desejou, Figueiredo iniciava a recapitulação de sua própria história. Uma obra literária, escrita em terceira pessoa, que em nenhum momento se apresenta como uma autobiografia, mas através das experiências de um personagem fictício traça os caminhos do próprio autor.

Em carta com ano de envio ilegível, mas provavelmente situada em 1944, o que deduzimos pelo contexto relatado, Rafael Altamira nos oferece também um exemplo das angústias provocadas pelo exílio. Neste período ele já se encontrava na França para onde foi após sua saída da Holanda em 1940. Lembramos que com a guerra civil na Espanha ele, que era juiz internacional, foi para Haia e de lá, em 1940, seguiu para a França onde permaneceu até 1944. Neste ano, partiu para Lisboa, depois para Nova York e só então se estabeleceu no México até sua morte em 1951. Foram, portanto, sucessivas experiências de deslocamento e afastamento durante um período de aproximadamente 15 anos que reúnem alguns dos mais importantes e difíceis acontecimentos da história da Espanha no século XX. Na carta endereçada ao historiador argentino Ricardo Levene, Altamira relata brevemente a situação em que vivia, diz que sair do país era "questão de vida ou morte" e pensa os possíveis lugares nos quais poderia se instalar. Diz a Levene que gostaria de ir para a Argentina para, em suas palavras, "viver meus últimos anos nesse país e com amigos como você que me fazem amar a vida e a humanidade" (ALTAMIRA, 1944) ${ }^{1}$. Ao final, acabou encontrando exílio no México. Finalizando a carta, deseja ao interlocutor argentino

\footnotetext{
${ }^{1}$ Carta de Rafael Altamira a Ricardo Levene. 19 de maio. A carta se encontra rasgada no lugar da data tornando o ano ilegível, mas provavelmente foi enviada da França em maio de 1944, já que nela Altamira fala dos acertos que sua família e amigos vinham fazendo desde março para seu exílio fora da Europa. Em novembro de 1944 ele se exilou no México. Acervo: Biblioteca, Museo y Archivo Dr. Ricardo Levene (Biblioteca Nacional de Maestros), Buenos Aires.
} 
aquelas que seriam as maiores satisfações da vida: saúde, não temer o dia de amanhã e "viver na pátria entre amigos" (ALTAMIRA, 1944). Satisfação da qual havia sido afastado há quase 10 anos e que não voltaria a experimentar até a morte.

Podemos dizer que a experiência do exílio acompanhou Figueiredo e Altamira em boa parte de suas trajetórias, gerando consequências na produção do conhecimento histórico. Por isto, nos interessa e instiga. Exílio vivido por intelectuais que compunham uma geração atordoada pelas guerras europeias, pelas ditaduras e perseguições políticas que caracterizaram seu tempo. Figueiredo e Altamira, evidentemente, não foram os únicos a viverem esta experiência, mas parte de um conjunto de expatriados, voluntária ou compulsoriamente, que tiveram que buscar em outros lugares o acolhimento que seus países não lhes ofereceram. A própria correspondência passiva de Figueiredo nos dá uma medida da importância da temática do exílio para esta geração. Além de Altamira, as cartas apresentam muitos remetentes europeus e ibero-americanos exilados por razões políticas.

Estas razões variavam de acordo com a posição ideológica de cada um e o momento histórico em que se deu o exílio. Muitos monarquistas foram exilados de Portugal e da Espanha a partir de 1910 e 1931, respectivamente, com a proclamação da República. Em Portugal isto se deu em grande parte devido à oposição ao primeiro presidente do Governo Provisório, Teófilo Braga (contra quem Figueiredo se opôs política e intelectualmente). Oposição muito vinculada ao campo católico contrário ao positivismo de Teófilo. O mesmo também se deu com republicanos que de primeira hora se satisfizeram com a República e, com seu desenrolar, acabaram retirando seu apoio e participando de movimentos de oposição. No caso português, José Hermano Saraiva (1981: 3) aponta duas tendências distintas que marcaram o início da República. Uma mais radical, apoiada na opinião popular, na busca por soluções rápidas e anticlerical. Outra moderada, almejando a conciliação de interesses e apoiada na alta burguesia republicana. Antonio Soares Amora (1989) diz que os mais radicais eram os chamados democráticos baseados na ideologia dos republicanos positivistas e socialistas da geração de 1870, dentre eles Antero de Quental e Teófilo Braga. Os moderados, por sua vez, queriam a pacificação política, a união dos portugueses e reformas baseadas em instituições tradicionais sem revolução ou radicalismos, sendo liderados por Brito Camacho e António José de Almeida. Figueiredo era um opositor intransigente do positivismo e de excessos de radicalismos, mas se posicionou em determinadas 
circunstâncias ao lado dos republicanos. Não obstante, sua formação e algumas escolhas políticas o levaram a ser classificado como monarquista e democrata.

Fidelino de Figueiredo, bem relacionado profissional e politicamente, chegou a ser nomeado diretor da Biblioteca Nacional de Lisboa por duas vezes, em 1918 e 1927. Foi também ministro do governo Sidónio Pais, de caráter bastante autoritário. Para Wehling, Figueiredo viu no sidonismo um "recurso provisório, que visaria à instauração da ordem e de um regime modernizador" (WEHLING, 1983: 20). Após o assassinato de Pais em 1918, Portugal viveu um período de grande instabilidade política que culminaria em 1926 no golpe de Estado responsável pela implantação do Estado Novo. Liberal que não se opôs diretamente ao conservadorismo de Pais, somente a partir de então Figueiredo começou a discordar dos rumos políticos do país. As agitações políticas foram intensas e em 1927 ocorreu a rebelião militar contra o governo republicano ditatorial (SARAIVA, 1981). Desde 1926, quando havia sido implantada a ditadura pelo golpe de 28 de maio, setores insatisfeitos do próprio Exército mobilizavam-se a fim de retomar o poder do Partido Democrático. Uniram-se a eles operários e outros partidos republicanos que seguiam em atividade apesar da repressão governamental. Ainda em 1926, outro grupo de oposição à ditadura passou a se formar na Biblioteca Nacional de Lisboa contando com a participação de republicanos como Raul Proença e Jaime Cortesão, vinculados à revista Seara Nova, que pegaram em armas durante o movimento em fevereiro de 1927. A rebelião é iniciada no Porto e, em seguida, expandida para as demais cidades e regiões do país. A repressão ao movimento é violenta e dezenas de revoltosos são fuzilados ou presos.

Como consequência, o controle ditatorial sobre as instituições aumenta e funcionários do governo e reitores de universidades envolvidos na rebelião são demitidos; além de vários intelectuais terminarem exilados, como ocorreu com Jaime Cortesão, Antonio Sérgio e o próprio Fidelino de Figueiredo. Como diretor da Biblioteca Nacional, Figueiredo participou do movimento ao lado dos intelectuais da Seara Nova. Não temos relatos sobre sua ação direta e armada, mas sabemos que ele sofre um suposto atentado, é demitido da Biblioteca Nacional e acaba preso e exilado. A partir daí é deportado para Angola e, logo depois, segue para o destino de sua primeira experiência de exílio: a Espanha. Foi convidado por Cirot para se instalar em Paris (destino da maioria dos intelectuais exilados da rebelião de 1927). Porém, se recusou e decidiu permanecer em Madrid, de onde, segundo García Morejón, "seria mais fácil sentir o pulso de sua Pátria” (MOREJÓN, 1967: 17). 
No país vizinho permanece por dois anos, entre 1927 e 1929 (durante a ditadura de Primo de Rivera), ditando cursos na Universidade Complutense de Madrid, aproximando-se de estudos sobre a história e a literatura espanholas e dedicando-se à crítica literária. Aproveitou também para ampliar sua rede de sociabilidade entre os intelectuais espanhóis, dentre eles Ramón Menéndez Pidal, Antonio Ballesteros y Beretta, Miguel de Unamuno e Rafael Altamira. Nesta ocasião desenvolveu uma aproximação pessoal e profissional com este último. Apesar da condição de exilado, desempenhou no país intensa atividade intelectual; como se lá houvesse encontrado a estabilidade, a inspiração e o acolhimento que lhe faltavam em Portugal, em razão do intercâmbio de ideias com seus pares espanhóis. Intercâmbio que, acreditamos, o influenciou nas décadas posteriores, sobretudo na busca pela inserção da Península Ibérica na modernidade e nas ideias americanistas de reaproximação com as antigas colônias. Assim, buscou transformar suas angústias em produção. Seria este um momento de amadurecimento intelectual (MOREJÓN, 1967).

Lembramos do que diz Carlos Altamirano a respeito da definição do próprio conceito de intelectual. O autor pensa os intelectuais de maneira conectada, como um grupo que se constitui, no caso latino-americano, no espaço urbano e em âmbito nacional, ainda que, em muitos casos, as redes por eles construídas tenham alcançado âmbito continental ou ibero-americano. Assim, seriam "pessoas, no geral conectadas entre si por instituições, círculos, revistas, movimentos, que têm como arena o campo da cultura" (ALTAMIRANO, 2008: 14). Daí a importância de se pensar a posição destes sujeitos no espaço social, suas associações e os embates nos quais atuavam; de se analisar as redes de sociabilidade por eles construídas, bem como sua circulação, viagens, intercâmbio e experiências de exílio. Por isso, a história intelectual não poderia ser, em sua análise, apenas uma história das ideias. Pensar as condições de existência dos discursos também seria fundamental. Os intelectuais constroem cenários próprios, de menor escala, grupos, redes, sociedades, através dos quais disputam espaço e atenção. Assim, na história intelectual, é preciso conjugar história das ideias, história da literatura, história política e sociologia dos intelectuais, além de outros campos como a história da imprensa, pois suas ações adotaram muitas formas distintas. É necessário entender ainda como estes sujeitos alcançaram visibilidade, ocupando espaços culturais e de poder. Acreditamos que esta abordagem se adeque à análise aqui proposta acerca de Figueiredo e Altamira. Pensados em diálogo, em rede, marcados por experiências construídas nos lugares espaciais e sociais que ocuparam e, no caso do recorte deste 
texto, pela experiência do exílio que contribui para um intercâmbio ibero-americano, o estudo destes intelectuais possibilita uma reflexão sobre diferentes questões referidas ao poder, às relações do seu grupo com a política, às condições de produção de conhecimento e de discursos e ainda à subjetividade transpassada por frustrações, angústias e ressentimentos.

Seguindo este caminho, cabe dizer que o ambiente intelectual do país se transforma no início da década de 1930 com a instauração da Segunda República Espanhola gerando conflitos para o exilado Fidelino de Figueiredo. Ainda em 1927, porém, sua relação com os escritores da chamada geração espanhola de $1927^{2}$, inclinados aos estudos da cultura portuguesa, se aprofunda ampliando sua aproximação com o país e as influências espanholas em sua obra, principalmente a partir do pensamento de José Ortega y Gasset. Exemplo dessa produtividade intelectual é o conjunto de ensaios intitulado Critica do exílio publicado assim que Figueiredo retornou a Portugal. Em nota explicativa do volume, o autor esclarece o contexto em que os ensaios foram escritos e destaca a necessidade de durante a experiência que viveu "esquecer muito e aprender alguma coisa". Diz, ao mesmo tempo, que os amigos do jornalismo, das letras e das universidades e academias fizerem do seu "exílio um tesouro de recordações" (FIGUEIREDO, 1930: nota de abertura).

Embora tenha se tornado um período de aprendizado e dedicação profissional, o exílio, evidentemente, não deixou de ser uma experiência geradora de melancolia e frustração. Um momento de afastamento, de ruptura, de medo do presente e do porvir, de perda de posição profissional... Assim, Fidelino de Figueiredo testemunhou o lado cruel da expatriação reconhecendo-a como um crime político, pois retira de uma vida seu significado, o sentido que a ambiência política, profissional e, ao mesmo tempo, pessoal e familiar lhe conferem. Retira-lhe a satisfação de "viver na pátria entre amigos”, apontada por Altamira anos depois quando do seu próprio exílio em 1944. Em suas palavras, no livro Notas para um idearium português, afirma: “[...] roubar a alguém a pátria é talvez o maior crime da malevolência política, porque é desenquadrar uma vida da moldura social que lhe dá significado e finalidade, é demolir toda a arquitetura de uma vida" (FIGUEIREDO, 1929: 221).

A decepção e o ressentimento não estiveram presentes apenas em exilados, mas em muitos que, como já sugerimos, se decepcionaram com a República tal como se

\footnotetext{
${ }^{2}$ Lembramos que a própria geração de 1927 viveu a experiência do exílio. Com o início da Guerra Civil Espanhola, vários dos seus principais nomes precisaram deixar o país.
} 
apresentou com o passar dos anos e com as ditaduras franquista e salazarista. $\mathrm{O}$ exílio pode, portanto, ser entendido como uma experiência ampla vinculada ao sentimento e ao posicionamento político e ideológico e não apenas ao deslocamento geográfico. Muitos, mesmo não saindo de seus países, se sentiram como tais a partir do momento em que foram presos e censurados pela República que antes defenderam. A decepção republicana marcou a geração de Figueiredo e Altamira e atingiu toda a Península Ibérica. Contudo, antes da proclamação da República espanhola em 1931, as medidas autoritárias da ditadura de Primo de Rivera (1923 a 1930) ${ }^{3}$ não atingiram a produção intelectual de Figueiredo no país quando lá esteve entre 1927 e 1929. No início também não atingiram os intelectuais espanhóis. Cabe destacar que aqueles oriundos do regeneracionismo e da geração de 1898 não viram com maus olhos a ascensão de um ditador militar. Somente com o passar do tempo e o fechamento de periódicos e a censura às Universidades de Madrid e Barcelona é que muitos deles, como Miguel de Unamuno, foram duramente perseguidos e tiveram que se exilar. Não foi o caso de Altamira que somente o fez com a guerra civil, mas a partir daí se tornou mais difícil circular suas ideias pelos meios políticos e intelectuais.

A partir da proclamação da Segunda República, no entanto, para os intelectuais ligados ao pensamento católico, os conflitos foram ampliados. A censura aos meios de comunicação e a perseguição anticlerical, com a ordem de dissolução da Companhia de Jesus e o confísco de seus bens, produziram a decepção de Altamira e principalmente do católico Fidelino de Figueiredo com o país que o inspirou e recebeu ${ }^{4}$. A instabilidade política aumenta com a guerra civil em 1936 e a partir de 1939 é instalada a ditadura de Francisco Franco que se prolonga até 1975. Contexto político que atinge diretamente a produção intelectual e reflete uma Península Ibérica abalada pela decepção diante das esperanças de futuro trazidas pelos regimes republicanos. De acordo com G. Ribbans (1982), a própria poesia espanhola entre as décadas, principalmente, de 1920 e 1940

\footnotetext{
${ }^{3}$ Primo de Rivera assumiu o poder a partir de setembro de 1923 por meio de um golpe no qual dissolveu a constituição e suspendeu o Parlamento. Prometendo uma recuperação do prestígio espanhol com base em princípios regeneracionistas, Rivera encontrou pouca resistência. Foi apoiado sobretudo pelo clero, pelas forças armadas e pelos setores conservadores, mas contou com a conivência ou a neutralidade de diversas outras correntes ideológicas, como os socialistas e os republicanos. No princípio, Altamira compunha estes grupos que o apoiaram.

${ }^{4}$ Lembramos que, segundo Gizlene Neder e Gisálio Cerqueira Filho, a Segunda República, iniciada em 1931, teve a tarefa de conjugar diferentes interesses e ideias (entre elas as de tradição e modernidade) numa conjuntura antagônica e contraditória. Assumindo uma postura anticlerical, acabou por enfrentar a oposição de intelectuais católicos que a identificaram como autoritária, sendo este o caso de Figueiredo (NEDER; CERQUEIRA FILHO, 1999: 89-109).
} 
apresenta as marcas destas transformações ao trazer uma preocupação eminentemente simbólica e sem compromisso social. Figueiredo declara sua decepção em Um coleccionador de angústias. Para ele, a propaganda republicana era utópica e quando chegou ao poder tornou-se demagógica e sangrenta, o que a fez enfrentar a oposição dos intelectuais que perderam sua independência e liberdade política (FIGUEIREDO, 1953).

Podemos dizer que as experiências políticas que levaram Figueiredo e Altamira ao exílio acabaram gerando consequências para a reflexão histórica, de modo que este se tornou um momento de forte produção intelectual. Contudo, se dissemos que eles transformaram o exílio em experiências produtivas, é preciso, por outro lado, enfatizar o quanto de incertezas e frustrações estes anos trouxeram a eles e a seus pares intelectuais que viveram o mesmo conflito. Longe de ser uma posição confortável, o exílio produz questionamentos, de um lado produtivos, mas, de outro, difíceis de serem superados. A incerteza põe em movimento, mas também gera sofrimento. Edward Said utiliza sua trajetória de exilado para refletir sobre esta experiência produtiva, mas dolorosa. $\mathrm{O}$ intelectual palestino lembra que o exílio faz pensar sobre ele, mas é extremamente difícil vivenciá-lo. O define destacando a separação por ele provocada entre o homem e seu lugar de origem, pelas perdas e mutilações que dele surgem. Definição baseada numa imagem parecida com o desenquadrar de uma moldura que, como vimos, fora utilizada por Fidelino de Figueiredo. A imagem que inspira Said é a de uma fratura, "uma fratura incurável entre um ser humano e um lugar natal, entre o eu e seu verdadeiro lar: sua tristeza essencial jamais pode ser superada" (SAID, 2003: 46). A tristeza é, deste modo, constitutiva da experiência do exilado, mesmo que dela se possa retirar momentos de aprendizado e curiosidade intelectual. Afinal, significa a perda de um lar e de toda a imagem de segurança que ele representa; significa sempre que algo foi deixado para trás. "O pathos do exílio está na perda de contato com a solidez e a satisfação da terra: voltar para o lar está fora de questão" (SAID, 2003: 52).

Para Said, se a literatura foi sempre recheada pelas aventuras de exilados, estas "não são mais do que esforços para superar a dor mutiladora da separação" (SAID, 2003: 46). O próprio Um coleccionador de angústias de Fidelino de Figueiredo é um livro que trabalha com as aventuras de um exilado, mas um exilado triste e angustiado. As aventuras de alguém que experimenta a sensação de não ser e não pertencer. Said destaca que em outras épocas os exilados também sofreram frustrações e mantiveram suas atividades enquanto viviam nesta posição. Porém, no século $\mathrm{XX}$, com as guerras, o 
imperialismo e os governos totalitários, viveu-se "a era do refugiado, da pessoa deslocada, da imigração em massa" (SAID, 2003: 47). Assim, amplo, trágico e representativo da intolerância política e religiosa, o exílio não pode ser visto como produtivo para o humanismo. Ainda que promova reflexões, não se deve banalizar suas mutilações e perdas.

O exílio não seria, portanto, uma condição privilegiada, mas sim uma alternativa surgida diante da intolerância e da perseguição a massas vítimas de tortura, crueldade e genocídio. "No fim das contas, o exílio não é uma questão de escolha: nascemos nele, ou ele nos acontece. Mas, desde que o exilado se recuse a ficar sentado à margem, afagando uma ferida, há coisas a aprender [...]" (SAID, 2003: 57). Fazendo parte de uma cultura e uma realidade as quais não pertence, o exilado vive experiências ambíguas e peculiares. A partir delas vê o mundo por um duplo ângulo que relaciona o que vive no momento e o que ficou para trás. Em outro de seus trabalhos, Said fala do "estado intermediário" do exilado que o relaciona a dois lugares, culturas, religiões, idiomas... Sendo assim, não está "nem de todo integrado ao novo lugar, nem totalmente liberto do antigo, cercado de envolvimentos e distanciamentos pela metade; por um lado, ele é nostálgico e sentimental, por outro, um imitador competente ou um pária clandestino" (SAID, 2005: 57).

Ao analisar a obra Mimesis, de Eric Auerbach, Said destaca sua produção no exílio em Istambul, o que representou a impossibilidade de acesso a bibliotecas e arquivos e resultou em um trabalho baseado principalmente na memória e no talento interpretativo do autor. Filólogo, especialista em línguas românicas, Auerbach procurou superar a belicosidade através do conhecimento humanista. Forçado pelos nazistas a sair de Marburg, em 1935, o autor produziu, como diz Said, um livro pessoal, de um exilado, um alemão afastado de suas raízes, apesar de sua grande erudição. Neste sentido, Mimesis é o produto das contradições de um judeu prussiano no exílio turco, da dialética entre o lugar do exílio e o de origem, do encontro entre um olhar de dentro e outro de fora das culturas as quais pertenciam. Daí que a obra e o autor sejam fundamentais em sua compreensão da experiência dos intelectuais exilados, o que inclui a sua própria experiência. Até sua morte, em 1957, ele teria desejado retornar a Alemanha, mas, mesmo assim, após anos em Istambul, construiu uma carreira em diferentes universidades nos Estados Unidos. Segundo Said, o grande triunfo de Mimesis é o fato de pensar a literatura ocidental a partir das limitações do seu próprio tempo e do seu próprio trabalho. Ou seja, no exílio de Auerbach há conquistas, 
produção, reflexão e, ao mesmo tempo, afastamento, sofrimentos e dificuldades concretas inerentes ao trabalho do erudito.

No caso de Fidelino de Figueiredo, o exílio na Espanha durou apenas dois anos, mas não foi o único. Menos de dez anos depois, no final da década de 1930, o intelectual buscou novamente refúgio fora do seu país. Experimentou pela segunda vez a sensação de não ser e não pertencer, mesmo que no Brasil, um país de cuja intelectualidade já havia se aproximado há tempos, com a mesma língua e profundas relações históricas e culturais. Em 1932, António Salazar assumiu a presidência do Conselho de Ministros de Portugal da qual se afastou somente em 1968. Católico e nacionalista, exerceu o poder político de forma autoritária, censurando e perseguindo a intelectualidade portuguesa que a ele se opunha. Posicionando-se ao lado destes opositores, Figueiredo tornou-se também alvo do autoritarismo salazarista. Veio para o Brasil somente em 1938, mas desde 1935 encontramos indícios de que sabia que uma nova saída de Portugal seria necessária. Com este objetivo, sondava seus colegas estrangeiros sobre oportunidades profissionais em seus países e enviava currículo para que fosse apresentado em universidades que pudessem recebê-lo. Ao que parece privilegiou a Ibero-América e acabou optando pelo Brasil, não sabemos se por proximidade cultural e intelectual ou porque aqui as oportunidades apresentadas foram maiores e melhores. Cabe lembrar que, talvez como alternativa ao contexto europeu e na tentativa de ampliar sua rede de sociabilidade fora de Portugal, Figueiredo viaja durante toda a década de 1930 ditando cursos em universidades estrangeiras como professor convidado.

Não temos notícias do seu processo de mudança para o Brasil até o ano de 1938. As cartas que recebia durante este período, talvez em razão da censura, tratavam basicamente da troca de livros e publicações. Na verdade, desde o ano de 1920, Figueiredo já demonstrava sua insatisfação com a conjuntura política portuguesa e seu interesse pelo Brasil. Em correspondência com Max Fleiuss, secretário perpétuo do IHGB, em vista de acertar os detalhes de sua visita já muito próxima ao país, ele deixa claros estes aspectos. Em carta datada de 27 de maio de 1920, fala a Fleiuss sobre sua paixão pelo Brasil, seu desejo de conhecê-lo e sua decepção em ser um autor pouco considerado e perseguido em Portugal. Nela o intelectual português descreve a satisfação com que recebeu carta anterior de Fleiuss, se apresenta como um exilado em sua própria pátria e afirma que muito lhe honraria uma ida ao Brasil (FIGUEIREDO, 1920). Em outra carta, de 11 de julho do mesmo ano, lamenta o isolamento e a 
perseguição sofridos em Portugal e comemora o fato de possuir colegas na Espanha e no Brasil que lhe prestam solidariedade naquele momento. Em suas palavras: "Tocamme profundamente essas manifestações neste momento em que recrudescem as perseguições e malevolências políticas. Infelizmente é sempre do estrangeiro que vêm as consolações" (FIGUEIREDO, 1920). Nesta mesma carta, ainda esclarece que não viria ao país apenas passear, mas sim pôr a sua "sinceridade intelectual ao serviço do Brasil” (FIGUEIREDO, 1920) e contribuir para o enriquecimento da cultura brasileira. Assim, se demonstrava insatisfeito com o não reconhecimento em Portugal desde 1920 e reforçava seu interesse por outros países, em especial Espanha e Brasil. Como vimos, primeiramente ele se exilou na Espanha, mas no final da década de 1930, diante dos prenúncios da Segunda Guerra na Europa, da guerra civil e do autoritarismo na própria Espanha, o Brasil parecia um destino mais apropriado. Neste contexto, a América Ibérica se tornou a melhor alternativa: o Brasil para Fidelino de Figueiredo em 1938 e o México para Rafael Altamira em 1944.

Enquanto esteve no Brasil, entre 1938 e 1951, dirigiu a cadeira de Literatura Portuguesa da Faculdade de Filosofia, Ciências e Letras da Universidade de São Paulo, participou da fundação da Faculdade Nacional de Filosofia do Rio de Janeiro, formou discípulos, tornou-se sócio correspondente da Academia Brasileira de Letras em 1942 (por intervenção de Alceu Amoroso Lima) e publicou vários de seus mais importantes livros $^{5}$. Enfim, mesmo como exilado, criou uma série de laços com o Brasil e os brasileiros. Aproveitou-se do "estado intermediário" do qual fala Edward Said e percebeu as oportunidades também trazidas pela sobrevivência entre dois países. Isto não quer dizer, não obstante, que a angústia e a saudade de Portugal não o tenham atingido.

A ida de Rafael Altamira para o exílio em 1936, com o início da Guerra Civil Espanhola, apresentou algumas particularidades em relação a Figueiredo e aos demais exilados de sua geração. Como juiz internacional, Altamira prontamente obteve autorização para deixar a área de conflito na Espanha, mas por suas funções na Corte de Haia não pode sair de imediato da Europa. Por isto, durante 4 anos, entre 1936 e 1940, permaneceu na Holanda. Em 1940, no entanto, enquanto muitos intelectuais europeus já se encontravam há tempos exilados na América, Altamira precisou deixar o país em

\footnotetext{
5 Entre eles, destacamos Aristarchos (1941), A luta pela expressão (1944), História da Literatura de Portugal (1944), Um pobre homem de Póvoa do Varzim (1945), A épica portuguesa no século XVI (1950) e Estudos de literatura (1951).
} 
virtude da invasão dos alemães. Seguiu para Bayonne na França onde viveu até 1944 quando, finalmente, com o auxílio do Instituto Carnegie e de alunos, colegas e diplomatas argentinos e mexicanos, partiu para Lisboa onde ficou alguns meses aprofundando o contato com intelectuais portugueses. De Lisboa embarcou para Nova York e logo depois para o México. Assim, Ascensión de León Portilla observa que a ida para o México, que foi um processo curto para muitos espanhóis naquele período, para Altamira se tornou "uma odisseia de cinco anos, uma espécie de inter-exílio longo, difícil, duro" (PORTILLA, 1990: 425). Portilla considera ainda que, para um historiador como Altamira, preocupado com a influência da psicologia humana nos acontecimentos históricos, a experiência do exílio, ainda que enriquecedora, "foi também motivo de amargura e desesperança" (PORTILLA, 1990: 425). Desesperança pessoal e política. Sentimento que experimentou em três ocasiões principais: em 1898, com a perda das últimas colônias espanholas; na guerra de 1914 a 1918; e agora com a guerra civil em 1936. Para Rafael Asín Vergara, "nas três a primeira reação de Altamira é a surpresa e o desgosto" (VERGARA, 1997: 61).

Nos anos de exílio, Altamira dedicou-se intensamente ao trabalho intelectual e, em meio a muitas de suas publicações, demonstrou insatisfação e decepção diante das guerras e do afastamento compulsório da Espanha. De acordo com Ascensión Portilla (1990), no exílio mexicano, Altamira se dedicou à pesquisa, à redação de livros e artigos para revistas e periódicos e ao contato com mexicanos e exilados como ele, espanhóis e estrangeiros em geral. Como temas, além da antiga reivindicação do papel da Espanha no mundo, enfatizou a busca de caminhos para a paz e o entendimento entre os países. Durante os 7 últimos anos de vida o trabalho docente também foi intenso. Contribuiu, inclusive, para a criação de importantes instituições como a Escuela Libre de Derecho, o Ateneo de la Juventud e o Ateneo Español de México e colaborou para a redação dos planos de estudos da Universidad Nacional Autónoma de México, além de ter formado gerações de historiadores e juristas no país. Neste período, se preocupou com o estudo da história universal e da compreensão dos homens e da cultura, tentando recuperar o otimismo perdido durante a Guerra Civil Espanhola. Ainda no exílio, em 1947, foi homenageado com o primeiro prêmio de História da América pelo Instituto Panamericano de Geografía e Historia em razão de sua obra americanista.

Quando chegou ao México, Altamira tinha já 78 anos. A idade o fez, além de produzir novos textos, dedicar-se também à recapitulação das principais bases do seu pensamento. Deste modo, investiu boa parte do tempo na organização e edição de suas 
obras completas, algumas já publicadas anteriormente, outras inéditas. Rafael Vergara considera que através desta atividade o historiador espanhol conseguiu recuperar seu otimismo e o sentido para a própria vida. O grande volume de trabalho e sua idade avançada não permitiram que concluísse a coletânea, mas deixou o projeto adiantado. Embora longevo, desde os primeiros anos de exílio, Altamira já apresentava saúde debilitada. Em artigo para o jornal La Nación em 1939, já se dizia velho e descrevia sua visão como precária, o que prejudicava seu hábito de leitura. Segundo ele, a fragilidade oriunda da idade avançada lhe permitia conversar consigo mesmo e cultivar suas memórias - imagem de fragilidade que contrasta com sua intensa atividade intelectual durante o exílio. Neste período vivendo na Holanda, se dizia solitário, mas com uma solidão povoada por suas memórias e pela atividade como juiz internacional. Aproveita para se dizer sempre desconfiado de juízos absolutos, de visões extremadas e ideias autoritárias, em uma clara referência aos conflitos europeus e, em especial, à violência da Guerra Civil Espanhola que tanto o atingira (LA NACIÓN, 1939).

Acrescentamos que Altamira teve a oportunidade de retornar com segurança à Espanha, mas acabou optando pela permanência no México. Ele queria voltar, assim como Fidelino de Figueiredo desejava o retorno a Portugal. Porém, concluiu que não valia a pena viver em um país controlado pela ditadura franquista. Nos últimos anos de vida, chegou a se declarar incompatível com um regime totalitário. Por isto, preferia permanecer na América até o fím do governo ditatorial, o que sabemos não ter presenciado em razão do seu falecimento muitos anos antes. Deste modo, optou por investir em sua produção intelectual como exilado mesmo diante dos danos materiais e imateriais que ele próprio alegava ter sofrido com o afastamento da Espanha. Virgilio Zapatero, ao tratar das traumáticas consequências do exílio para os intelectuais, diz que Altamira "havia perdido sua casa, sua família, seus amigos, sua biblioteca, seu trabalho, seu otimismo e quase, dizia ele, até sua confiança no gênero humano" (ZAPATERO, 2006: 6). Para o autor, o exílio traz dois grandes traumas: o abandono de tudo o que se ama e o esquecimento. Isto porque a repressão e o próprio transcorrer do tempo ameaçam apagar as obras e a memória dos exilados. Segundo ele, a ditadura franquista teria conseguido por muito tempo tornar milhares de espanhóis invisíveis. Possivelmente foi por esta razão que Altamira se dedicou no exílio a reunir e reeditar o principal do seu pensamento - como na Europa o contexto político dificultava a concretização deste objetivo, o fez na América, foco de suas atenções durante décadas de trabalho como historiador. 
Este processo de esquecimento atingiu a obra de Altamira. Durante a ditadura franquista ele praticamente não foi estudado e suas obras não foram reeditadas na Espanha ${ }^{6}$. O hispano-americanismo por ele defendido foi neste período apropriado pelo conservadorismo católico e perdeu seu conteúdo pacifista e liberal; acabou servindo aos interesses da ditadura ao adquirir sentidos autoritários. Na América Ibérica a ascensão de governos ditatoriais no pós-guerra e a força do imperialismo norte-americano acabaram também tomando a maior parte do espaço antes ocupado pelas ideias hispanoamericanas. Seu pensamento e obra voltaram a ser tema de interesse somente a partir do final do século XX quando, após o fim da Guerra Fria e a queda do muro de Berlim, o debate sobre integração obteve maior destaque na Europa e na Ibero-América. Além disto, após a operação franquista de destruição da história democrática na Espanha, o ensino da história voltou a interessar a historiadores e professores nos anos 1970, em consonância com o enfraquecimento da ditadura. Isto explica em parte a publicação da segunda edição do La enseñanza de la historia de Altamira apenas em 1997, mais de 100 anos após sua primeira versão incompleta datada de 1891.

\section{Exílio, Reconhecimento e Ressentimento}

A análise acerca das experiências de exílio de Fidelino de Figueiredo na Espanha, entre 1927 e 1929, e no Brasil, entre 1938 e 1951, e de Rafael Altamira na Holanda, entre 1936 e 1940, na França entre 1940 e 1944, e no México, entre 1944 e 1951, sugere uma reflexão sobre reconhecimento e ressentimento. Isto porque o exílio traz em si a representação de obstáculos e limitações que se impõem à busca de reconhecimento e legitimidade. $\mathrm{O}$ exílio em si representa uma forma de rejeição à cultura, à religião, à origem ou às ideias de alguém. Uma forma de rejeição bastante extrema que implica o abandono do trabalho, da casa, dos familiares e amigos... Enfim, da própria terra natal, parte fundamental da identidade do indivíduo. A exclusão, a não aceitação, a rejeição, o não ser e não pertencer presentes no exílio acabam por gerar ressentimento, conceito diretamente relacionado ao de reconhecimento. A partir do momento em que falta satisfação com a própria identidade e aprovação do grupo no qual se insere, a busca por reconhecimento acaba transpassada pelo ressentimento.

\footnotetext{
${ }^{6}$ As obras de Altamira impressas a partir da década de 1940 foram todas publicadas em países hispanoamericanos, sobretudo México, Argentina e Uruguai.
} 
Para Claudine Haroche (2000), a busca por reconhecimento nas sociedades democráticas contemporâneas enfrenta um paradoxo situado numa suposta igualdade de direitos não acompanhada por igualdade social. Os indivíduos acreditam que são iguais, mas lidam constantemente com situações que os diferenciam. A igualdade relaciona-se com um direito de reconhecimento pautado no mérito. Reconhecimento que somente adquire validade quando legitimado pelo Outro. Por isto, o indivíduo tem necessidade de olhar o Outro e ser olhado e admirado por ele, pois sua legitimidade, de suas ações e ideias, depende do olhar do sujeito sobre si mesmo e dos Outros sobre ele. O reconhecimento pauta-se, deste modo, numa relação direta com a sociedade a qual pertencemos e nos valores morais, políticos e econômicos que a fundamentam. Haroche afirma ainda que "o ressentimento aparece então como uma resposta inconsciente, efeito longínquo de uma angústia ignorada, recalcada, ligada ao sentimento ameaçador de uma negação da existência" (HAROCHE, 2004: 340). Segundo Tzvetan Todorov, o reconhecimento é responsável pela entrada do indivíduo na existência humana. Quando falta reconhecimento, surgem sentimentos de frustração, decepção e angústia, já que a própria existência enquanto ser humano foi negada. A perseguição, o afastamento e a exclusão que caracterizam o exílio são formas claras de se negar reconhecimento e, consequentemente, a existência a alguém. O mesmo autor aponta duas etapas na busca do reconhecimento: a primeira seria o reconhecimento de nossa própria existência e, a segunda, a confirmação do nosso valor. Esta dissociação seria fundamental por provocar reações específicas: "podemos ser indiferentes à opinião dos outros, mas não conseguimos ficar insensíveis à falta de reconhecimento de nossa própria existência" (TODOROV, 1996: 94).

Os sujeitos históricos traçam, ao longo de suas trajetórias, caminhos específicos para o alcance de reconhecimento e legitimidade, pois vivem diante de um todo social do qual desejam pertencimento, admiração e respeito. A rejeição deste mesmo grupo, da terra natal, do lugar de origem, produz insatisfação e a sensação de não se ter um lugar específico. O não acolhimento gera decepção e ressentimento diante da incompreensão e da intolerância. O próprio Todorov lembra que desde o nascimento o ser humano é inserido numa rede de relações sociais que deve reconhecê-lo. Ao longo da vida, o indivíduo busca, além disto, conferir sentido, significado a esta existência e se utiliza de vários caminhos condizentes com a cultura e o grupo social do qual faz parte. Caso este reconhecimento não seja alcançado, o indivíduo apresenta diferentes tipos de reação: a obtenção de aprovação, tentando conquistá-lo novamente e fazer melhor da próxima 
vez; o reconhecimento de substituição, a partir da transgressão da regra comum que não foi capaz de integrá-lo; e a renúncia, através da recusa do contato com o mundo externo a si mesmo. Embora não estejamos interessados em classificações, talvez a reação de Fidelino de Figueiredo ao exílio enquanto não reconhecimento tenha sido a tentativa de reconquistá-lo, de tentar de novo a fim de ser aceito, como fez ao voltar para Portugal em 1929, após sua estadia na Espanha, e em 1951, depois de treze anos no Brasil. Altamira, como vimos, também desejou este retorno ao país de origem, mas não no contexto político no qual ele se encontrava. Acabou morrendo antes de concretizar seu desejo de ver a Espanha redemocratizada. De todo modo, ambos buscaram a ruptura com o isolamento através do diálogo com seus pares de diferentes nacionalidades e da produção intelectual e do trabalho docente no exílio. Afinal, inserir-se no intercâmbio cultural e de ideias e rever a própria obra, é reafirmar a existência de si, para si e para os Outros. Para Todorov, "intensificar o intercâmbio social significa intensificar o eu" (TODOROV, 1996: 159).

O desejo de retorno de Figueiredo e Altamira à Península Ibérica sugere a busca pela retomada da vida que tinham antes do exílio, de voltar a ser e a pertencer, de retomar uma identidade que lhes conferiria uma, talvez ilusória, sensação de estabilidade. No Brasil e no México, Figueiredo e Altamira viviam em países com a mesma língua e relações históricas e culturais muito próximas com seus lugares de origem, mas não se sentiam em casa. Não se sentiam parte do mundo que prioritariamente desejavam que os reconhecesse. Suas identidades estavam incompletas. Há, de certo modo, uma relação entre o exílio, a perda e a reorientação e autorreflexão acerca da própria trajetória intelectual. Esta perda não pode ser reduzida a ponto de ser vista como positiva, como lembrou Edward Said, pois traz um sem-número de frustrações intelectuais, profissionais, políticas e afetivas. Não podemos, contudo, deixar de perceber em Figueiredo e Altamira a presença de um ressentimento que produz resultados positivos: os fez produzir conhecimento como forma de suavizar a dor e a frustração do exílio e do não acolhimento. A produção intelectual pode ser uma forma de superação da sensação de não ser e não pertencer provocada pelo exílio. De suavizar e/ou manifestar o ressentimento oriundo do não acolhimento em seus países ou grupo social de origem. A escrita e o diálogo com seus pares intelectuais são parte das alternativas por eles criadas para a superação do ressentimento. 


\section{Considerações Finais}

O exílio que afastou Fidelino de Figueiredo e Rafael Altamira de Portugal e da Espanha também os aproximou das antigas colônias americanas. Isto ocorreu na medida em que o contexto de guerras e radicalização política europeu levou a se pensar a América como uma alternativa pacífica, um refúgio para intelectuais ibéricos insatisfeitos, inadaptados e perseguidos em seus países. Como exilados, eles se angustiaram e ressentiram, mas, ao mesmo tempo, puseram em prática suas ideias americanistas. Figueiredo e Altamira experimentaram os governos autoritários das décadas de 1920 e 1930 na Península Ibérica e a ascensão de Salazar e Franco. Foram perseguidos e exilados. Ambos viveram um total de 15 anos de suas vidas no exílio. Boa parte deles na Ibero-América. Para ambos, o exílio teve fim no mesmo ano, 1951 Figueiredo pelo retorno a Portugal e Altamira em razão do seu falecimento aos 85 anos de idade. Coincidências que aproximam suas trajetórias pessoal e profissional. Embora distintos ideologicamente, viveram as consequências da radicalização política e da violência que assolaram a Europa no início do século XX. Uma Europa que produziu toda uma geração de intelectuais exilados na América Ibérica, na África e nos Estados Unidos. O exílio coincidiu entre estes indivíduos tornando-se uma experiência fundamental não apenas para eles, mas para toda uma geração. O não ser e não pertencer inerentes ao exílio compuseram boa parte do seu pensamento e da sua obra.

Uma suposta função pacifista da história, que havia se fortalecido após a Primeira Guerra, durante as décadas de 1930 e 1940, com a Guerra Civil Espanhola e a Segunda Guerra, ganhou ainda maior destaque no pensamento destes intelectuais. Tanto Figueiredo, com sua visão cosmopolita, quanto Altamira, defendendo uma história geral da civilização que integrasse as diferentes culturas, viram na pesquisa e no ensino da história a possibilidade de evitar animosidades através do conhecimento mútuo e recíproco. Esta ideia circulava nas duas margens do Atlântico, conferindo ao conhecimento histórico sentido político e caráter de utilidade para o presente. Acreditamos que a experiência do exílio tenha contribuído para acentuar ainda mais esta percepção da história como necessária para suavizar os conflitos e as angústias do presente, o que nos é sugerido pela própria produção intelectual de Figueiredo e Altamira durante e após o exílio. Olhar para as outras culturas, se aproximar delas e compreendê-las foram exercícios favorecidos pela história e, na prática, pelo exílio. 
Deste modo, neste artigo pretendemos conjugar a experiência do exílio às questões subjetivas e às ideias de intelectuais cujas trajetórias foram transpassadas pelos fascismos nas primeiras décadas do século XX na Península Ibérica. Destacamos suas relações com instituições e intelectuais da Ibero-América durante o exílio ou mesmo fora dele e pensamos como este intercâmbio foi importante na produção de conhecimento, inclusive de um conhecimento histórico marcado pelo americanismo e pela defesa do recrudescimento das relações entre antigas metrópoles e colônias num contexto de guerras europeias. Pensamos estes sujeitos conectados entre si e com outros, a partir de redes de sociabilidade, que os influenciaram em suas ideias e viabilizaram a própria sobrevivência em períodos de guerra, fascismo e exílio. Com isto, o lado angustiante e o lado inspirador e desafiador do exílio se encontram e atuam diretamente sobre a atuação e a obra destes intelectuais. Simultaneamente, relacionamos o exílio ao par reconhecimento / ressentimento, entendendo-o como parte da formação dos intelectuais e das suas relações com seus pares e países de origem e de exílio. Estas questões compõem a experiência do afastamento e as escolhas políticas e pessoais destes sujeitos em momentos de conflito. Neste sentido, consideramos que Fidelino de Figueiredo e Rafael Altamira sejam casos exemplares a serem analisados não apenas separadamente, mas em conjunto, em razão das suas experiências comuns, conforme buscamos demonstrar ao longo deste artigo.

\section{Fontes}

ALTAMIRA, Rafael (1997 [1891]). La enseñanza de la historia. Madrid: Ediciones Akal.

. La soledad poblada. La Nación, 11 de junho de 1939.

FIGUEIREDO, Fidelino de (1930). Critica do exilio. Lisboa: Livraria Clássica Editora. (1929). Notas para um idearium português: politica e litteratura. Lisboa: Sá Costa.

(1953). Um coleccionador de angústias. Lisboa: Guimarães Editores.

Cartas de Fidelino de Figueiredo a Max Fleiuss. 27 de maio de 1920 e 11 de julho de 1920.

Carta de Rafael Altamira a Ricardo Levene. 19 de maio de 1944.

\section{Referências bibliográficas}

ALTAMIRANO, Carlos (dir.). Historia de los intelectuales en América Latina. I. La ciudad letrada, de la conquista al modernismo. MYERS, Jorge (ed. del volumen). Buenos Aires: Katz 2008. 
AMORA, Antonio Soares (1989). O essencial sobre Fidelino de Figueiredo. Imprensa Nacional. Casa da Moeda.

AYALA, María de los Ángeles (2006). Cartas inéditas de Rafael Altamira a Domingo Amunátegui Solar. Cuadernos de América sin Nombre, n. 14. Alicante: Universidad de Alicante.

(2004). Elementos para uma antropologia política do ressentimento: laços emocionais e processos políticos. In: BRESCIANI, Stella e NAXARA, Márcia (Org.) Memória e (Res)sentimento: Indagações sobre uma questão sensível. Campinas: Editora da Unicamp. (2000). Les paradoxes de l'égalité : le cas du droit à la reconaissance. In : KOUBI, G. E GUGLIELMI, G. Les égalités des chances. Paris : La Rècouverte.

JUAN, Eva Maria Valero (2002). Rafael Altamira y la 'patria intelectual' hispanoamericana. América sin nombre, n. 3, Alicante, junho de 2002.

(2003). Rafael Altamira y la 'reconquista espiritual' de América. Murcia: Universidad de Alicante.

LÖWY, Michael. Sobre o conceito de afinidade eletiva. In: Redenção e Utopia: O judaísmo libertário na Europa Central (Um estudo de afinidade eletiva). SP: Cia das Letras, 1989.

MOREJÓN, Julio García (1967). Dos coleccionadores de angústias: Unamuno y Fidelino de Figueiredo. SP: Faculdade de Filosofia, Ciências e Letras de Assis.

NEDER, Gizlene; CERQUEIRA FILHO, Gisálio (1999). Ecos da Segunda República e da Guerra Civil Espanhola no Brasil. Revista Tempo, Niterói, v. 4, n. 8, dezembro de 1999.

PORTILLA, Ascensión H. de León (1990). Los exilios españoles. El exilio de Altamira. Biblioteca Jurídica Virtual. Universidad Nacional Autónoma de México, México, vol. 5 , n. 15, set a dez.

RIBBANS, G. (1982). La literatura española después de 1700. In: RUSSELL, P. E. (ed). Introducción a la cultura hispánica. I- Historia, arte, música. Barcelona: Editorial Crítica - Grupo Editorial Grijalbo.

SAID, Edward (2007). Introdução a Mimesis, de Eric Auerbach. Humanismo e crítica democrática. SP: Companhia das Letras. (2003). Reflexões sobre o exílio e outros ensaios. SP: Companhia das Letras. (2005). Representações do intelectual. As conferências Reith de 1993. SP: Companhia das Letras.

SARAIVA, José Hermano (1981). História concisa de Portugal. Lisboa: Publicações Europa-América.

TODOROV, Tzvetan (1996). A vida em comum: Ensaio de antropologia geral. Campinas: Papirus.

VERGARA, Rafael Asín (1997). Estudio preliminar. In: ALTAMIRA, Rafael (1997 [1891]). La enseñanza de la historia. Madrid: Ediciones Akal, 1997.

WEHLING, Maria José (1983). A ideia de história em Fidelino de Figueiredo. Dissertação (Mestrado em Filosofia) - Departamento de Filosofia, Universidade Gama Filho, Rio de Janeiro.

ZAPATERO, Virgilio (2006). El legado constitucional del exilio. Espacios y protagonistas del exilio. Fundación Pablo Iglesias, 3 a 6 de fevereiro.

Artigo recebido em 15 de agosto de 2019.

Aprovado em 10 de novembro de 2019. 